\title{
Teaching Comparative Literature in English(es): Decolonizing Pedagogy in the Multilingual Classroom
}

\author{
Birgit Mara Kaiser (D)
}

\begin{abstract}
This article reflects on the challenges that arise when the comparative literature classroom, especially in the Netherlands, is increasingly multilingual and simultaneously increasingly monolingual in its focus on English as a primary language. In view of moving comparative literary studies beyond its Eurocentric framework, what opportunities lie in teaching translated texts in "English(es)" in such a multilingual setting? What are the effects of such an interplay of mono- and multilingualism in view of a commitment to decolonizing the literary curriculum and pedagogical practice? What attention to language and linguistic difference might be available given the diverse linguistic and cultural literacies of students? Less interested in questions of translating texts, the article pursues how teaching literary texts in translation can foster listening to linguistic difference and encourage relational attunement when degrees of literacy and illiteracy are shared at varying levels of competence across students and teachers.
\end{abstract}

Keywords: comparative literature, multilingualism, decolonial pedagogies, methods of reading, translation

As a literary scholar interested in the materiality of language and the performativity of reading, I cherish attention to textual composition and linguistic detail when teaching literature in the classroom. It is the attention to detail, as well as the experience of textual opacity and alterity that Spivak notes as central elements of a literary education, one that

Birgit Mara Kaiser is an associate professor of comparative literature and transcultural aesthetics at Utrecht University in the Netherlands. Her research spans literatures in English, French, and German from the late eighteenth to the twenty-first century, with special interest in aesthetics, affect and subject-formation, postcolonial literary studies, and critical cultural studies. Book publications include Figures of Simplicity. Sensation and Thinking in Kleist and Melville (SUNY 2011), Singularity and Transnational Poetics (ed. Routledge 2015) and Symptoms of the Planetary Condition: A Critical Vocabulary (Meson Press 2017, ed. with K. Thiele and M. Bunz). She has recently contributed to Comparative Literature, Interventions, Parallax, Textual Practice and PhiloSOPHIA: A Journal of Continental Feminism. With Kathrin Thiele, she is founding coordinator of Terra Critica: Interdisciplinary Network for the Critical Humanities (www.terracritica.net) and editor of the book series New Critical Humanities with Rowman \& Littlefield International. 
can train the imagination "into a will for peaceful social justice." ${ }^{1}$ Teaching in comparative literature-more so than, for example, in programs of English, French, or Hispanic literature-raises a crucial question in that regard, namely how to foster attention to linguistic detail and the challenges of (un)translatability, when students read a significant number of texts in English translation and when for the majority of these students English is a second language. This is at least the case in Dutch universities, where I teach. Often, my students express that they experience reading in translation as reading at a remove or as making it impossible for them to address questions of linguistic or poetic composition. Although my own research engages with (postcolonial) literatures written in French, German, and English (with excursions into writings in Spanish and Dutch), my teaching in comparative literature at Utrecht University indeed draws mostly on texts in English, many of which are translated into English, including from other languages than the five I can read. In this short contribution, I want to reflect on both the challenges and potential gains that arise from what I experience, on the one hand, as an increasingly monolingual classroom in its focus on English as the primary language (in terms of the texts we read and as language of instruction), and yet simultaneously, on the other hand, as an increasingly multilingual space that includes many languages of which I as a teacher have no reading knowledge. In what follows I want to think about the effects such an interplay of monolingualism and multilingualism might have in view of a commitment to decolonizing the literary curriculum and pedagogical practice.

In part, the seemingly paradoxical situation of an increasingly monolingual yet also increasingly multilingual classroom has to do with the geopolitical location of the literature programs in which I teach. In recent years, Dutch universities, and especially Utrecht University, have pushed for an internationalization of study programs, which means that more bachelor's and master's programs are offered in English. Until 2015, courses in most of these programs were taught in both Dutch and English, and applying to a study program required that students have a command of both languages on an academic level. Since then, most master's programs at Utrecht University have adopted English as their primary language of instruction, and in the case of comparative literature, since 2017, also the bachelor's program offers an all-English taught track, next to a bilingual track taught in Dutch and English. ${ }^{2}$ This transition has led to an increase in international students, from other European countries as well as from a wide range of non-European countries. In the academic year 2019-20, about 50 percent of incoming bachelor's students and 30 percent of incoming master's students in our literature programs are from outside the Netherlands. For my specific teaching context, this has meant going from a largely Dutch-speaking student body with English as a

1 Gayatri Chakravorty Spivak, Readings (London and Calcutta: Seagull Books, 2014), 6.

2 To be precise, the master's program "Literature Today" at Utrecht University offers three tracks: English and comparative literature (taught in English), Dutch literature (taught in Dutch and English), and modern European literature (taught in French, German, Spanish and English). The second and third tracks have challenges of their own in view of the bilingualism they demand. My reflections here are based on my teaching in the English and comparative literature track of this master's program as well as my teaching in the English-taught track of the bachelor's program, and I am especially interested in the increasing multilingualism in these classrooms, where English is the lingua franca, but neither is it the only language spoken, nor a first language to most students, nor the only language from which literatures are considered. 
second language (usually also their only operative second language) to a multilingual classroom with an increasing diversity of languages other than English or Dutch. Although we work with literary texts almost exclusively in English translation (even if encouraging students to read the original) and our lingua franca is "English(es),"3 students bring a much larger linguistic variety into the classroom than they did a few years ago. Just thinking of the literature classes I taught in the academic year 2018-19, students were native speakers of Arabic, Bangla, Bulgarian, Cantonese, Croatian, Dutch, different variants of English, French, German, Hindi, Iban, Igbo, Japanese, Malay, Mandarin, Romanian, Papiamento, Portuguese, different variants of Spanish, and Turkish. In 2019-20, the situation is approximately the same in terms of variety, although each year is different in terms of which languages are in the mix. This year, my students have native competence in Arabic, Catalan, Danish, Dutch, Farsi, French, Frisian, German, Greek, Hindi, Iban, isiZulu, Italian, Luxemburgish, Malay, Mandarin, Romanian, Russian, different variants of Portuguese, Polish, Spanish, Turkish, and in a few cases (New Zealand, South African, British, and US-American) English. As someone interested in the materiality of language and the performativity of reading, as stated previously, but also concerned with unlearning the colonial politics of language inherent to the field of comparative literature, I find these changes in the classroom exciting. Compared with a few years ago, it means that students have a larger sensibility for language and linguistic differences than students who operate, as if naturally, in their native language with "global English" as their only other language. Furthermore, the use of English as a shared tongue occurs in an academic setting, where English (unlike, say, in UK or US universities) is not the national language and hence to a degree a "foreign" yet shared tongue. Because one of my pedagogical goals is fostering a critical sensibility for textual opacity and the materiality of language, as well as for the challenges this generates for our processes of reading, this is a welcome change. ${ }^{4}$

The question that has preoccupied me as a result of this change is how such an increased sensibility to living "in languages" ${ }^{5}$ might assist also in teaching reading as a mode of critical engagement that neither leaves a text untouched as impenetrably other (and thus capitulates before beginning to read) nor appropriates it as transparent

3 The agrammatical term English(es) has in mind Emily Apter's use of the plural "Frenches" in "Theorizing Francophonie," Comparative Literature Studies 42.4 (2005): 297-311, where Apter tries to unwork the dominance of hexagon French as the "real blueprint" of the language and to loosen the isomorphic equation of nation/language. "Frenches"-or Francophonie as a concept-is "designating no single people or nation, but a linguistic multiple of extra-hexagonality irreducible to the sum of regional and ethnic idioms that comprise it" (Apter, 300). As a vehicle and remnant of colonial expansion, English is in a similar position to French-a language no longer designating a single people or nation - and it is lived as an increasing mix of "Englishes" in my courses. On the diversification of language, see also Barbara Cassin, who notes that "la multiplicité n'est pas seulement entre les langues, mais en chaque langue" ("Présentation," in Vocabulaire Européen des Philosophies. Dictionnaire des Intraduisibles, ed. Barbara Cassin (Paris: Editions du Seuil, 2004), $\mathrm{xx}$ ).

4 I am thinking here especially of Edouard Glissant's notion of opacity. In Poetics of Relation (Ann Arbor: The University of Michigan Press, 1990), Glissant writes, in distinction to the "requirement for transparency" (190) in Western thought, that "the opaque is not the obscure" (191) and that the right to opacity is "not enclosure within an impenetrable autarchy ... but would be the real foundation of Relation" (190). It is this negotiation of relational differences, in the multilingual classroom as well as in the varying accessibilities of a text it enables, that I have in mind when using the term.

5 Cassin, "Présentation," xvii. 
sameness (that is, overreads or underreads textual difference and opacity). These are surely two extremes of a spectrum of reading approaches, but they are indications of the attitudes to reading in translation that are often at play in my classroom. The former resonates in statements from students such as "I wouldn't know what to say about this text because I cannot read it in the original and know little about the cultural or historical context from which it emerged," which I hear frequently when teaching texts in English translation. What students express here, it seems to me, is a hesitation to engage with what is on the page because they might not fully understand, feel unable to get to the original "true" text, or do not feel at home with its diction or setting. The text then remains largely untouched as unknowable, and where (self-)recognition and identification are felt to be impossible, withdrawal, often expressed as a form of respect, is the response. The assumption of transparency, which insufficiently respects textual difference and opacity, on the other hand, plays out when students ignore the fact that the text speaks to a situation or raises questions that might not be fully translatable to their own experience, such as when they feel they can fully identify with the issues raised, thereby often reducing or overlooking the concrete stakes of this text, how it might be speaking to poetic, historical, cultural, or philosophical concerns that are different from the reader's experiences. As Spivak suggests, the negotiation of difference and sameness manifested in these responses to texts might also speak by implication to their negotiation in other than textual realms. A literary education, she notes, might help to work readers away from an appropriation of otherness into sameness and toward a more generous "relating to the other" as Other, potentially opaque, but not therefore unreadable. A literary education in this sense would mean training students to pay close attention to linguistic and aesthetic detail, to grapple with textual opacity and alterity, with the meaningmaking that texts initiate and demand, and to affirm this grappling also as an experience of the limits of one's own interpretations and the need to stretch one's imagination. ${ }^{7}$ Such an attention can give rise to what Spivak calls the ethical: an attitude toward the Other that interrupts epistemological "capture" and can contribute in small ways to "rearrange desire" 8 and train the imagination toward, as we read previously, "a will for peaceful social justice." 9 The wager is that by teaching literary reading, as a training in negotiating the limits and potentials of our understanding of (textual) otherness, we wrestle with our negotiation of (cultural) difference and (un)translatability. I subscribe to this hope that the medium of language and the poeticity of the literary can contribute to rewiring our perceptions of otherness and the ethical in Spivak's sense.

From this perspective, I want to consider now how to teach reading as such a close attention to literary texts, in order to facilitate the (infinitely slow and incalculable) rearranging of desire. I am convinced that such an attention harbors the ethical potential

6 Gayatri Chakravorty Spivak, "Translation as Culture," in An Aesthetic Education in the Era of Globalization (Cambridge, MA: Harvard University Press 2012), 252.

7 I am drawing here explicitly on Spivak, but we find a similar argument (equally inspired by Derridean deconstruction) in Derek Attridge, for example, The Singularity of Literature (New York and London: Routledge, 2004), or J. M. Coetzee and the Ethics of Reading: Literature in the Event (Chicago: University of Chicago Press, 2004).

8 Spivak, “Translation as Culture," 255.

9 Spivak, Readings, 6. On the ethical and epistemological, see also Gayatri Chakravorty Spivak, Ethics and Politics in Tagore, Coetzee and Certain Scenes of Teaching (Oxford: Oxford University Press, 2019). 
to learn to respectfully approach otherness, which Spivak and others have argued for, and that such relearned attention is an important element of decolonizing pedagogies. Given the specific situation of teaching comparative literature in the Netherlands, I ask myself how to foster such an experience of reading/alterity under the condition that we are teaching texts mostly in English translation. Thus, what I am concerned with here are the challenges and opportunities that arise from working with translated texts, especially in a multilingual classroom. I am less interested here in questions of translating texts. Whereas the methodological debates in comparative literature in the past decades have often been critical of world literature's affirmation of translation and have perceived English (and working with translated texts) as a threat to linguistic proficiency and to the comparative literary methods of attending closely to texts, I would like to ask instead what opportunities, in view of moving comparative literary studies beyond its Eurocentric framework, might lie in teaching translated texts in "English(es)" in a multilingual classroom. ${ }^{10}$ What attention to language and linguistic difference might be available in a multilingual classroom that we could tap into in order to learn "how to read" in a context in which texts cannot be assigned in their original versions?

Although I certainly do not wish to weaken a demand for sophisticated linguistic and cultural literacy, an affirmation of teaching translated texts under those conditions might, first of all, have the productive effect of expanding and diversifying the curriculum beyond the European canon that has dominated comparative literature for far too long. The narrow set of European languages shared by scholars in the discipline is no longer tenable in view of the global plethora of literary languages and the endeavors to move the discipline beyond its Eurocentric and colonial framework. But rather than only thinking about what we read, I want to think about decolonizing pedagogies in the literary classroom in view also of how we read. It seems to me important to stress that part of a move toward decolonizing pedagogies in literary studies lies in enabling an attitude toward reading texts that refuses being stuck in the positions of either "I cannot know this foreign text" or "this text speaks for and about me." As well as expanding the canon, a move to decolonizing pedagogies might require relearning relations to/of otherness; and striving for patient, generous encounters with texts, based on study and curiosity (etymologically derived from Latin curiosus (careful, diligent, inquiring eagerly) and related to cura (care)), might be one way to practice a potential understanding and listening to the opacities that defer and destabilize meaning. In calling such a practice "decolonizing," I am thinking concretely of Rolando Vázquez Melken's notion

10 For the debates around translation studies, World literature and new comparativism on expanding the archive or altering modes of reading, see exemplarily: Emily Apter, The Translation Zone (Princeton: Princeton University Press, 2004); Stephen Best and Sharon Marcus, "Surface Reading: An Introduction," Representations 108.1 (2009): 293-321; David Damrosch, How to Read World Literature? (Hoboken, NJ: Wiley-Blackwell, 2008); Franco Moretti, Distant Reading (London: Verso, 2013); Gayatri Chakravorty Spivak, Death of a Discipline (New York: Columbia University Press, 2003); Lawrence Venuti, The Translation Studies Reader (London and New York: Routledge, 2004). Surely, Dutch higher education does not escape the dominance of global English, but the question of teaching texts in English translation might pose itself slightly differently in the Netherlands than it does, for example, in the United States, where much of the methodological debate around comparative literature/world literature was generated and where English is the national language, or, for example, in formerly colonized countries, where English was one of the colonial languages. 
of a decolonial aesthetics of listening. He notes that "decolonial critique aims to foster spaces where the listening of what has been relegated to oblivion becomes possible... . Decolonial critique and the humbling of modernity work in the epistemic field to open spaces for the listening of the voices from the outside of modernity." 11 Although Vázquez phrases listening as a critical mode that strives to attend to epistemic fields outside modernity, I am expanding Vázquez's use of listening here to a more broadly conceived attention to otherness and textual opacity. But in resonance with the deconstructive concern of Spivak, Attridge, and others for an ethics of reading, Vázquez also highlights the ethical that inheres in such a mode of listening. "The task of listening," he writes, "presents itself also as an ethical orientation, towards knowledge as relationality. To listen means to bridge the colonial difference, the rift that separates the visible and the invisible, 'the real' and 'the absent.' It poses the challenge to listen to those who have been disavowed and silenced." 12 The openness to listen for what seems at odds with our expectations or cultural repertoire is what resonates for me here when thinking of teaching literature in the multilingual classroom.

One could argue that this type of readerly attitude-of reading as listening to the text, listening for what has (not) been said-can be practiced without further ado in a monolingual classroom. The close attention to linguistic materiality and textual ambiguities might even be easier to achieve with students who have a native command of the language in which they are reading. Advanced literacy (including cultural literacy) is usually considered a prerequisite for solid close readings that can sense a text's richness or depths; also in comparative literature, near-native mastery of the languages whose literatures one engages has been a methodological touchstone and one of the key issues in world literature/new comparativism debates. Again, it is by no means my intention to propose that scholars of comparative literature should abandon the methodological demand of sophisticated linguistic and cultural literacy. But for teaching the reading of literature in the classroom, the multilingual situation described previously-in which a variety of languages and cultural literacies are present and English(es) is the lingua franca-might also offer the chance to explore new possibilities of and for reading. The difference that my multilingual comparative literature classes of recent years might offer vis-à-vis either the monolingual study of literature in, for example, programs of English, French, or Hispanic literature or the formerly bilingual classroom (Dutch native, English as second language) is the combination of linguistic proficiency and nonproficiency in an environment in which this can become shared experience. What I mean is that a variety of languages is present in the classrooms I am speaking of here (including hegemonic languages, minority languages, and languages from the South), and potentially, literatures from these languages (in translation) can be discussed in a comparative literature course. Students share degrees of bilingualism or multilingualism, as well as

11 Rolando Vázquez Melken, "Towards a Decolonial Critique of Modernity-Buen Vivir, Relationality, and the Task of Listening," in Capital, Poverty, Development. Denktraditionen im Dialog: Studien zur Befreiung und Interkulturalität, ed. Raúl Fornet-Betancourt (Aachen: Wissenschaftsverlag Mainz, 2012), 241-52, esp. 243.

12 Vázquez Melken, "Towards a Decolonial Critique of Modernity," 247. In another resonance, Spivak writes that "there must be a presumed collectivity of listening and countersigning subjects and agents in the public sphere for the subaltern to 'speak"' (Ethics and Politics in Tagore, Coetzee and Certain Scenes of Teaching [Oxford: Oxford University Press, 2019], 24). 
sophisticated, though varying levels of English; they also share the realization that others are proficient in languages they are not and that they are proficient in languages others are not. In my experience, this mix of competence and noncompetence, of (cultural) literacy and nonliteracy, can foster a pedagogical space of difference and relationality, in which attendance to the poetic density of texts becomes possible in new ways, even if (or perhaps because) texts come in English translation. This mix of multilingual (non) competence invites listening to textual composition and opacity in ways that might disrupt the linguistic and literary expertise in, say, English, French, or Hispanic literature, to stay with the aforementioned examples. The multilingual comparative literature classroom harbors degrees of linguistic competence and illiteracy experienced on everyone's part, and as such lends itself to being activated as a collaborative space of learning; as a space in which difference is experienced as enriching and the opacity of texts can be perceived (and partly unlocked, partly observed) in collaborative reading. In my experience, a crucial element of such a pedagogical practice is that the teacher also partakes in it-as both a facilitator of collaborative learning and a part of it, willing to acknowledge their own mix of literacy/expertise and illiteracy/noncompetence. ${ }^{13}$

Concretely, this means that I am (also) teaching literatures from languages I do not read, and I invite the active collaboration from students. Although I take Spivak's stress on unlearning one's privilege to heart, I thus depart from her dictum to teach literature only from languages one can also read and take inspiration here rather from bell hooks' Teaching Community: A Pedagogy of Hope, affirming that the noted interplay of competence/noncompetence does not exclude me as a teacher. ${ }^{14}$ The different linguistic and cultural attunements and competences in my classrooms can then help make, as hooks notes in view of antiracist pedagogies, "the classroom a place ... of liberating mutuality where teacher and student together work in partnership" 15 in which to practice attention to textual, poetic material together. Surely, the multilingual classroom also exceeds the European linguistic spectrum that still dominates comparative literature as a field and can heighten the willingness to reach and read for literary imagination and linguistic texture beyond the small set of European languages. Expanding the

13 Pedagogies that strive to question the colonial legacies inherent in globalized academia (or strive to "decolonize" the university) also need to critically reflect (and act) upon the structural inclusions/exclusions and the "governing fictions" (Fanon) that still continue within academic institutions. The notion of a master who transmits knowledge and controls its reception seems to be one of those persistent governing fictions in academic practice. If one strives to facilitate an experience of alterity/otherness for students, taking the teacher out of that experience would seem to defeat the very endeavor. Although pedagogies that try to question the conventional relation of master/disciple might come up against institutional demands of evaluation and assessment, what I reflect on here as a collaborative exercise is not incompatible with institutionally required assessment and grading. Even if such attempts might always be in a (hopefully critical, productive) tension with institutional (and students') expectations, giving attention in the classroom to collaborative close examination of texts and to explorations of shared knowledge and its limits does not foreclose gradable assessment and evaluation. Rather, I would venture, it trains a particular kind of attention to text in a social situation, in which one's capacity or incapacity to understand plays a crucial role.

14 For Spivak's stress on unlearning one's privilege, see Sara Danius, Stefan Jonsson, and Gayatri Chakravorty Spivak, “An Interview with Gayatri Chakravorty Spivak,” boundary 220.2 (1993): 24-50. Next to bell hooks' pedagogical reflections in Teaching Community: A Pedagogy of Hope (New York: Taylor \& Francis, 2003), Jacques Rancière's The Ignorant Schoolmaster: Five Lessons in Intellectual Emancipation (Stanford: Stanford University Press, 1991) comes to mind.

15 bell hooks, Teaching Community, xv. 
comparative literature canon beyond that narrow linguistic tradition must bear institutional fruit (in hiring policies, possibilities for language acquisition, and so on); it is (or will be) a crucial step to decolonize the curriculum, one that will also have to negotiate between reading in translation and literacies in more non-European languages. But the current situation of the "international" classroom, in which English(es) are the lingual franca and texts must be made available in English, has offered me food for thought on how to assist the experience of reading as grappling with alterity, on how to train a critical sensibility for the material aesthetics of texts under conditions of translation. ${ }^{16}$ In the past few years, it has raised the question of how to teach these practices to students who do not share one another's linguistic repertoires, but meet on the common denominator of English(es), and whose literacies I do not want to limit to mine. By way of closing, I would like to share now an example of my efforts at mobilizing students' linguistic and cultural inventories to help enable such close, collaborative reading experiences.

For a course in the research master's Comparative Literary Studies, I assigned the short stories "Mutterzunge" (mother tongue) and "Grossvaterzunge" (grandfather tongue) by Turkish-born Emine Sevgi Özdamar, who writes in German. I made the texts available in the original version and English translation. Two students in the class (one from Austria, one from Argentina) read them in German, the rest of the class (including a student from Turkey) read them in English. The stories are the opening pieces of Özdamar's collection Mutterzunge (1990) (Mother Tongue [1994]): the linguistically extremely rich texts play with various dialects and linguistic nuances (moving from high German with unmarked poetic evocations of Hölderlin to mimicked broken German associated with first-generation immigrants); their narrator reflects on the assumptions around a mother tongue, on Turkish language politics, on Germany's Nazi past, on German unification in the 1990s, as well as German migration politics since the 1960s. I assigned them because their varied pitches of German perform "mother tongue" as something acquirable and versatile, thus challenging ideas of unified national language and cultural nativism.

Much of the linguistic play is lost in the English translation, but the two interconnected stories also tell a very sensuous love story between a Turkish girl living in Berlin and her Palestinian teacher of Arabic, a narrative that students could access and enjoy. The girl takes Arabic lessons to (as she says) write to her grandfather, who would have written Turkish in Arabic script, before Atatürk's language reforms Latinized Turkish writing in 1928. Although she and her teacher communicate in German (and the story performs the various nuances of German mentioned previously), the text also

16 Reading as grappling with alterity is not predicated on reading in translation or in a multilingual setting. Far from it. The experience of alterity inheres in the specific attention that literature tout court demands due to its specific mode of veridiction and poeticity, as well as the ambiguities inherent to language (cf. Attridge, The Singularity of Literature), which also makes it impossible to tell once and for all whether a certain instance is a moment of alterity or simply not yet sufficiently unpacked. Learning to navigate that tension without retreating to "anything goes" is, it seems to me, the task of learning "how to read." What I have experienced, however, is that the shared space of competence and noncompetence, which the multilingual classroom opens up, can help create an environment in which students experience and negotiate their own competences and noncompetences (and this mix as a condition shared with others) and are willing to stay with that negotiation for a little longer. 
unearths the close linguistic kinship between Arabic and Turkish. Long passages in "Grossvaterzunge" are German translations of Turkish songs, presented in tandem with Koranic verses, all rendered in German, but marked in the narrative as deriving from Turkish or Arabic. In the course, we discussed how both of Özdamar's stories dwell on the linguistic triangle of Arabic, Turkish, and German; a tangle, in which the narrator finds herself and from which she fabricates a (for lack of a better word) translingual sense of self, despite the fact that social ascriptions of Turkish-German existence push her onto either side of the presumed binary. ${ }^{17}$ Most students could see this on the narrative level, but not so immediately on the linguistic, as, for example, the pun in the title Mutterzunge (a twist of the idiomatic Muttersprache, meaning mother tongue, but literally "mother language," foregrounding corporeal experience in language as well as intimacy and malleability) had to be retrieved through German. The translation only gives the English idiomatic mother tongue, a correct translation, which, however, domesticates the strangeness of the German original and obfuscates the pun's point. As a speaker of German, and together with the two students who had read the stories in German, we could facilitate this difference between German and English for the classroom, so that students not versed in German could retrace it and experience the importance of translation and the peculiarity of each language. The pun is double, however, because the foreignized German Mutterzunge derives from a literal translation of the Turkish ana dil, meaning mother tongue, and-like English, but unlike German-literally connoting the mother's tongue (dil). Having published on Özdamar before, in our discussions, I could also point out to the class the layering of German and Turkish at this very instance. But it was only with the help of the Turkish-speaking student that we were also able see how "Grossvaterzunge" draws on and transforms the wording of popular Turkish songs, which to me had remained unreadable as songs and which I had understood to be creative translations of the Koranic verses they are coupled with. Although they are instances of the narrator's effort at learning Arabic, it was with the student's cultural knowledge and ear for Turkish that we could unlock how Özdamar not only inscribes her protagonist into an idiosyncratic, new German, but how this German also runs on a Turkish cultural subtext, offering-in the evocation and twisting of popular songs-a humorous commentary on Koranic verses and Turkish politics.

Should I teach Özdamar in the future, the possibility of producing all of this in the classroom in an interplay of (student/teacher's) competences and (teacher/student's) noncompetences hinges to a degree on the presence of speakers of Turkish and German. More generally speaking, attention to textual materiality and aesthetics in this vein then depends to a certain degree on the composition of each classroom and it requires careful (curious) attunement each time anew to the specific mix of literacies and illiteracies in the room. ${ }^{18}$ The pedagogical point, however, is that greater attention to poetic detail and the experience of reading was possible in collaboration across the languages present in

17 For translingual, see Stefan Helgesson and Christina Kullberg, "Translingual Events: World Literature and the Making of Language," Journal of World Literature 3 (2018): 136-52; for Özdamar defying binary ascriptions, see Birgit M. Kaiser, "A New German, Singularly Turkish: Reading Emine Sevgi Özdamar with Derrida's Monolingualism of the Other," Textual Practice 28.6 (2014): 969-87; Yasemin Yildiz, Beyond the Mother Tongue: The Postmonolingual Condition (New York: Fordham University Press, 2011).

18 Other examples could be given. In 2018-19, in a course in the master's program, we were reading Spivak's "Translating into English," a text about translation and Farhad Mazhar, the renowned poet from 
that specific classroom (Turkish, German, English, only two of which I as teacher am proficient in). It happened in the interplay between my guidance and expertise and students' cultural and linguistic repertoires so that we could attend to what happens between German and English and to the Turkish intricacies in the text. The students who were more closely involved in this session (the speakers of German and Turkish) experienced such a flipped classroom as both challenging and inspiring, unexpectedly being the ones who know (in parts even more than the teacher). And the students without knowledge of German or Turkish were made aware that linguistic nuance and poetic playfulness are present and important in these texts and that students contributed to their unlocking, even if they themselves did not "master" all the languages at play. Within the debates on the futures of comparative literature, this might be one way in the very practice of teaching to confront the lasting Eurocentrism of the discipline's language politics and the colonial legacies of Western academic methodology and pedagogy more broadly: affirming a collective multilingualism in the classroom, operable through a spectrum of English(es) and an encouragement of linguistic difference and relational attunement to them shared at varying levels of competence across students and teachers. Such teaching practices might make the classroom a space for more decolonial pedagogies, dedicated to listening to otherness across colonial and linguistic divides and to redirecting our reading attitudes toward less appropriative modes of knowing, toward noncolonial negotiations of difference.

Bangladesh. Spivak makes important points on the task of the translator, on the politics of language in the concrete case of Bangla, as well as the larger point of languages being palimpsestic and historically as well as asymmetrically entangled, about the materiality and sound-scapes of a language that are next to impossible to translate, and about poetry as a mode of commenting on, yet undercutting nationalist (and in this case secular) narratives of a national collective. I assigned the text for these points. However, Spivak also at times closely engages with wording in Sanskrit and Bangla to make her points. I do not know either of these, as Spivak presumably expects to be the case for most of her readers. At one point, she transliterates a "famous pair of Sanskrit tags .... a. shushkum kashthum tishthattugrey b. neerasa taruvara poorata bhaati” (in An Aesthetic Education in the Era of Globalization, 256-74, esp. 265), a phrase attributed to a former schoolteacher of hers. She notes that both mean "there's a dry branch in the way" and invites the reader to see if they can "sense the complete dissonance in the two sets of sounds" (265). I could point students to the different assonances in both and explain Spivak's point that "sound and sense play together to show that translation is not merely transfer of sense" (265). However, it took the contribution of a student who had joined the program from Dhaka and his cultural literacy in Bangla and linguistic literacy in Sanskrit to make available to us the phrases' different sociopolitical associations and the richness of cultural context, in which one or the other would resonate. Indeed, as Spivak also notes in passing, "Sanskrit is not just a moment in Benveniste" (265), but it took the student's cultural literacy to flesh out how the two phrases function differently, despite "meaning" the same thing. The exact same lesson was not reproducible in the same course this year because we lacked the knowledge of Sanskrit and Bangla, while the other points (and new points) could be discussed. 